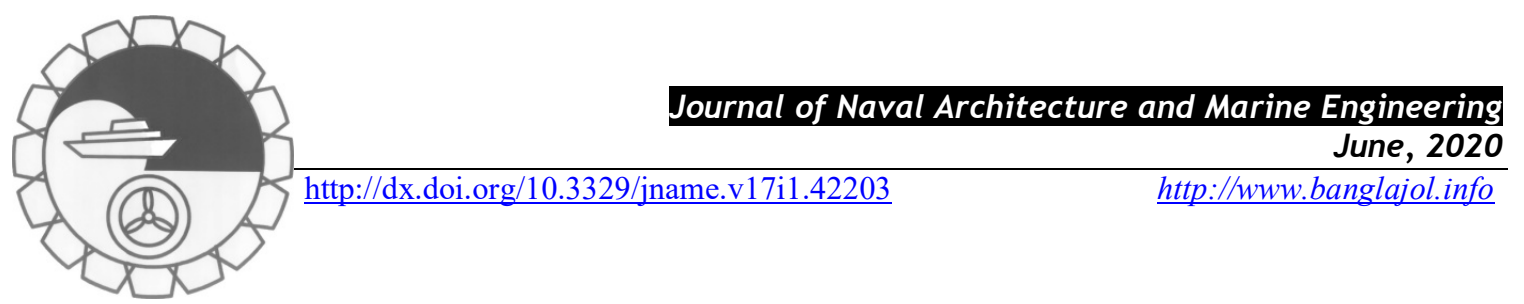

\title{
E-LEARNING IN MARITIME AFFAIRS
}

\section{S. Galić ${ }^{1}$, Z. Lušić ${ }^{2}$ and T. Stanivuk ${ }^{3}$}

${ }^{1}$ University of Split - Faculty of Maritime Studies, Croatia, Email: stipe.galic@pfst.hr

${ }^{2}$ University of Split - Faculty of Maritime Studies, Croatia, Email: zvonimir.lusic@.pfst.hr

${ }^{3}$ University of Split - Faculty of Maritime Studies, Croatia, Email: tatjana.stanivuk@pfst.hr

\begin{abstract}
:
E-learning has become a widespread form of education as it allows the users a relatively easy access to needed information. E-learning has also been present in maritime affairs, although not so ubiquitous as in other economy sectors. Sea-borne shipping is one of the most stringently controlled industries, with a number of complex regulations and standards. This paper analyses learning methodologies and discusses the economic justification of implementing e-learning systems at global level, with an emphasis on the growing e-learning industry, corporate segment of e-learning, massive open online course market, and the importance of the micro-learning concept. In addition, this study analyses the present systems of seafarers' education and the potentials, strengths and shortcomings of the conventional learning, e-learning and m-learning. Moreover, the recent application of e-learning in maritime affairs and the need of further research of the e-learning impacts in maritime affairs are examined. Finally, the presented information and discussion result in the logic matrix analysis and the SWOT analysis of e-learning, aiming to define the strengths, weaknesses, logic of action, goals and potentials of the implementation of e-learning in maritime affairs.
\end{abstract}

Keywords: E-learning, education of seafarers, STCW convention, IMO.

\section{Introduction}

E-learning has become a widespread form of education. It comprises information and communications technology (ICT) that allows the user a relatively easy access to needed information. E-learning is the second most important method used by organisations and companies. Its basic definition implies the use of multimedia and the Internet with the purpose of enhancing the quality of learning by facilitating access to distant sources and services and enabling the cooperation and communication among distant entities, i.e., it contains the socalled E-learning Strategy Task Force (ETF) (Delen, 2014). Quality web-based content and learning methods with adequate tools for self-assessment are the main features that distinguish e-learning from conventional inclass teacher-student environment. E-learning relies on quality and thoroughly developed programs and selflearning content in order to enable students to become a competitive workforce in the maritime market. As these new education and training systems are surrounded by fierce competitors, it is necessary to identify and analyse their advantages and disadvantages. A basic learning content includes an Internet application for accessing the Internet browser through personal computers. Connection to the Internet is an essential prerequisite. These programs are available at the Internet servers that are typically located in the institutions that provide the possibility of creating e-learning courses and that, in doing so, become places for storing, organising and sharing self-teaching materials, question asking and answering, solving on-line tasks, etc. A good example is Moodle, probably the most popular e-learning system that is globally used (Bauk, 2013). Education technology is not limited to high-tech solutions. However, electronic education technology, also known as e-learning, has become part of modern society and is constantly adopting various information services and devices. E-learning facilitated by hand-held devices, such as mobile phones, pocket PCs and personal digital assistants (PDAs), is called m-learning. Learning and teaching via mobile devices is growing rapidly because they are cheap, easy to carry and handle, and they provide instant access to educational material. Learners can share lessons plans, exchange advice, opinions and tips or immediately apply their knowledge, such as in on-the-job and just-in-time training.

\section{Learning Methodologies}

When performing standard face-to-face classes, a teacher has to acquire specific skills to make conventional education methods efficient. One of essential teaching skills is the ability to establish communication with 
students. Well-prepared lessons, clarity of explanation, accurate assessment of time constraints and clear teacher-student and student-student communication are some of the vital aspects. It is necessary to make records in all stages of the process to achieve efficient self-organisation, develop teaching skills and, using one's own errors, improve the quality of teaching, as suggested by the diagram in Figure 1.

Successful education implies efficiency and motivated audience. Generally speaking, a teacher's greatest challenge is to motivate students. When a student is interested in lessons and other learning activities, he or she becomes self-motivated and the teacher's performance will have long-term effects, even if the teaching content has been forgotten. If the teacher is familiar with strengths and weaknesses of the student, adequate steps for correct preparation of learning activities can be taken to mitigate weak points keep the audience focused (O'Dwyer, 2001).

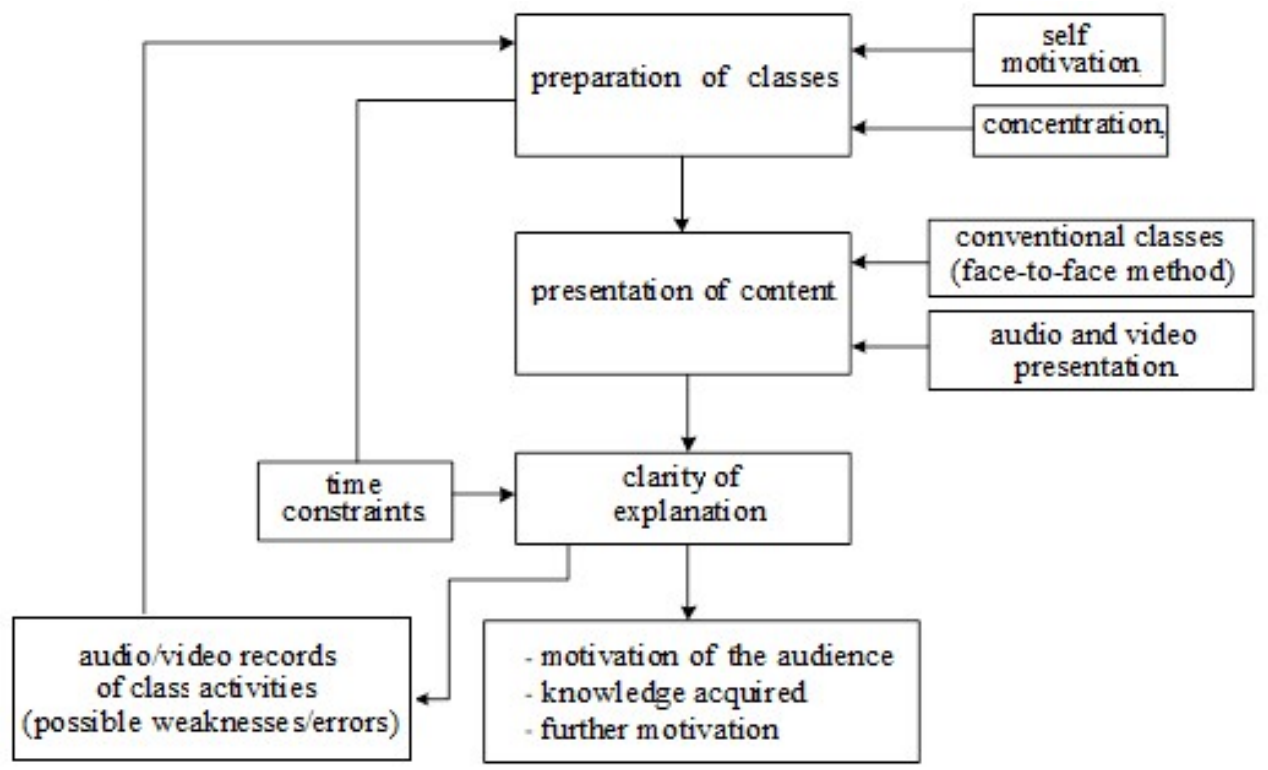

Fig. 1: Art of teaching

Computer Mediated Communication (CMC) is a form of education, i.e. human-human interaction mediated by networked computers or mobile telephony, whose intrinsic feature is distance between the teacher and the student. Therefore, its efficiency essentially relies in the communication between teachers / instructors and learners and is achieved only when the methodology incorporates the methods encouraging best communication potentials (Koroleva, 2018). Once thought as predominantly text-based interaction, CMC can now be performed via e-mail, Internet Relay Chat (IRC), interactive Internet games, or the so-called Multiple User Dungeons (MUD), news groups, virtual conferences, etc. (Huang, 2014). This way of communication plays an important role in the process of distance-learning as it makes the information delivery efficient. CMC can provide a communication flow that is similar to traditional learning but it also allows connections among teaching skills and various online learning interactions. The end result primarily depends on the teacher's capacity to motivate and encourage students to use a variety of methodologies and approaches.

Constructive learning is an effective methodology that promotes distance-learning activities. By using this approach, students can be actively engaged in using interactive e-mail, chat-room, bulletin boards or Internet browsers that further improve their learning skills and results. Collaborative learning is an education method where students, at various performance levels, take part in small teams and work their way towards a joint goal. Here, students are responsible for each other's learning performance and a student's success helps other students to be equally successful. This methodology is efficient in distance learning and is particularly focused on higher education community. One of the advantages of e-learning is that it allows the users to participate in learning activities efficiently, even with restraints such as distance, disparate schedules and other adverse circumstances. Wide availability allows many users to take part in the activities at the same time. There are five key factors in e-learning: advice providing or consulting, content, technology, services and support. Quality web-based content and learning methods with adequate tools for self-assessment are the main features that distinguish e-learning from conventional in-class teacher-student environment. Modern e-classroom is open 24/7 and allows a very 
efficient use of time. Learners can choose when and how to access e-learning platforms as they can constant access to the education materials and the learning process they are engaged in. E-learning enables an exceptionally dynamic student-teacher and student-student interaction. Each individual contributes to the process by logging in, i.e., by participating in tasks and discussions related to specific topics. The system allows simple integration and access to other relevant learning sources. On the other side, the major drawback of elearning is that the user has to have knowledge and certain skills to become part of it. Without adequate computer literacy, the content integrated in the e-learning system is completely useless. In addition to knowledge and skills, the e-learner is supposed to have dedicated equipment whose reliability is essential. Even state-of-the-art devices adapted for e-learning may fail. Although this does not necessarily results in the interruption of e-learning, technical problems certainly demotivate and reduce user concentration and, consequently, reduce the quality of the e-learning process. Being allowed to select the learning form and time independently, e-students take a great deal of responsibility. In some forms of e-learning, students have to selfmotivate and self-assess their need for learning, which may lead to questionable results and poor progress in the learning process.

Mobile learning, or m-learning, is a process taking place when a student is not at a fixed, pre-determined location, or a process taking place when a student benefits from mobile technology and its potentials. In other words, m-learning is the form of e-learning which is facilitated by hand-held devices, such as mobile phones, pocket PCs and personal digital assistants (PDAs). These technologies offer communication channels via e-mail, access to the Internet and voice and text messaging. Learning and teaching via mobile devices is growing rapidly because they are cheaper and easier to carry and handle than desktops, in addition to providing instant access to educational material. This is why it has become an important part of learning that has now becoming available anywhere, anytime, to anyone. Learners can share lessons plans, exchange advice, opinions and tips or immediately apply their knowledge, such as in on-the-job and just-in-time training. M-learning can take place anywhere. However, in order to be competitive with other forms of education, m-learning must meet three essential requirements: it must be embraced by the students, it has to achieve good learning outcomes, and stay cost-efficient (Marc, 2012). Moreover, the process must include the education and training of the staff who make decisions on the importance and effectiveness of m-learning. The key elements of mobile services include the possibility for learning at various locations, learning in personal environment, access to databases, interactive connection with teachers and other students, ability to analyse information within the student environment, and equal distribution of learning content across stationary and mobiles platforms.

While numerous advantages encourage the use of mobile learning in corporate environment, decision-makers in some companies or institutions perceive a number of drawbacks to be resolved. An analysis of the m-learning strengths and weaknesses may easily lead to an impression that m-learning is just a shift of the present learning methods onto mobile devices. However, modern approach to m-learning can make use of the smart technologies such as taking over the learning content that is useful to students and supporting them in line with their individual abilities. The present experience indicate that the m-learning in corporate environment is still in its early stage of development and that much effort must be made to turn m-learning into an important part of the professional education. There is uncertainty and various expectations regarding the new approaches to $\mathrm{m}$ learning usage, including the conviction that, for instance, learning through play and entertainment should not be used. This clearly indicates that there is doubt that the new approaches to m-learning could include serious games as an alternative way of learning. This is not entirely justified as the m-learning tools have great potentials and may change the ways of learning and yield significant results even in the corporate environment.

\section{Economic Justification of Implementing the E-Learning Systems at Global Level}

The e-learning industry is in full swing. The increasing number of organisations and companies turn to elearning as it enables benefits in various sectors. The learning environment has changed in the past ten years, following the advancements in e-learning and mobile technologies over the years. There has been a dramatic increase in companies using online training methods, mostly due to reduced technical constraints and changes in the users' priorities in terms of self-paced learning. The global market of e-learning will readily grow at a Compound Annual Growth Rate (CAGR) of about $7.0 \%$ in the following decade and will reach approximately 331 billion dollars by 2025 . Some of the prominent trends include an increased demand for distance-learning, governmental programs and incentives, an increased penetration of the internet and mobile learning, recent technological developments in e-learning, and growth and investment opportunities (Accuray Research LLP, 
2019). Growth rates indicate that all countries embrace e-learning as it offers a variety of benefits. Many universities are seeking non-profit models, using standard ways of learning blended with e-learning environment. When a company or an education institution performs a program based on e-learning, then it also requires a management system, or the so-called learning management system market (LMS) for maintaining and running such a program. Research results reveal that $74 \%$ of the companies use LMS for managing and maintaining e-learning programs (Accuray Research LLP, 2019).

Popularity of e-learning has been also affected by the trend of growing sales of smart phones and growing access to the Internet globally. According to the research, tablet computers are the most commonly used in the category of mobile devices. Tablets are as functional and mobile as smart phones but they also feature a larger screen and enough processor strength to replace notebooks in most situations. A great deal of tablets and mobile phones feature a number of tools and applications such as cameras, Global Positioning System (GPS) technologies, touch-screen, web browser, e-mail, etc. They increase the user's working performance and encourage the concept of m-learning in terms of the trend named Bring Your Own Device (BYOD) which is simply inevitable today.

Vendors have been increasingly focused on the design and distribution of learning courses at competitive prices, trying to gain a share in the global market of e-learning. The exponential growth of smart phone users and internet accessibility across emerging markets are driving the growth of e-learning market in these regions. The introduction of cloud-based learning and AR/VR mobile-based learning is likely to revolutionize the e-learning market during the forecast period.

The growth of the global e-learning market has been fostered by the increasing number of mobile users and the growing trend of learning through social media. E-learning content designers are focusing on developing very small and targeted lessons, or bit-sized lessons, and deploying learning modules in sprints to match the daily routine of mobile users. Services providers are developing new e-learning content through continuous news feeds, peer-to-peer challenges, flashcards, and content collaboration to attract consumers and introduce learning modules. The growth of the social media allows and encourages the emergence of new education paradigms such as hybrid and online learning. These new learning methods ensure the maximum amount of engagement levels and offer flexibility to end-users. The development of new modules will result in to the growth of the elearning market. By the mode of learning, the e-learning market can be classified into self-paced and instructorled learning. The self-paced learning mode was the largest segment in the e-learning market accounting for over $77 \%$ of the total market share in 2017 and is expected to reach $\$ 43.54$ billion during the forecast period (Accuray Research LLP, 2019).

North America had about 50\% of the total self-paced learning market share in 2017. The growth of this segment in the global e-learning market is driven by the increasing preference toward continuous learning and using technology to access content anytime and from anywhere. The growing demand for self-paced learning module from the corporate sector will create new opportunities for vendors in this market during the forecast period. They are already introducing technology-enabled tools that can facilitate the engagement of users, motivate learners, and help in collaborations, thereby increasing the market share and attracting new consumers to the market. The growth of the e-learning market will be further encouraged by the growing popularity of combined, or blended, learning where traditional instructor-led training is supplemented with electronic formats, which enhances the efficiency of learners. The e-learning market is expected to generate revenue of $\$ 65.41$ billion by 2023, growing at a compound annual growth rate (CAGR) of $7.07 \%$ during the forecast period (Arizton Research, 2018).

According to the type, the e-learning market is classified into training and testing segments. The training segment has dominated the e-learning market, making almost $39 \%$ of the total market share in 2017 , and is expected to reach revenue of $\$ 55.15$ billion during the forecast period. The training segment functions through the interaction of the users with the course holders and contents or with the global learning management systems (LMS). This type of learning module includes a wide range of audio and video content that can be streamed or stored according to the needs and requirements of the learners. The growing demand for LMS systems from professional, governmental-related, and academic sectors is fostering the growth of the training segment in the global e-learning market.

The market of the so-called Massive Open Online Course (MOOC) is in full swing and may, in many cases, replace LMS. Many companies cooperate with the MOOC providers (such as Coursera, Udacity etc.) that have 
established connections with the first-rate universities in order to place come of their courses on the web, thus enabling courses in various science branches to be available on-line. It is expected that the concept of microlearning will be increasingly important as the education institutions and companies are focusing on personalised and adapted learning. Micro-learning helps in acquiring certain information at short intervals. These courses provide efficient support for just-in-time learning as the bit-size information can be used for addressing individual gaps in learning.

According to the end-user type, the e-learning market can be classified into primary school, secondary school, university, corporate, government and vocational segments. The corporate segment was the fastest growing enduser segment in the global e-learning market generating revenue of $\$ 12.85$ billion in 2017. It is expected to grow at a CAGR of $9.76 \%$ during the forecast period. It is also expected that the further growth of the corporate sector in the e-learning market will be driven by a shift toward cloud-based learning that is cost-effective, efficient, and time-saving (Arizton Research, 2018).

In terms of geography, the e-learning market comprises North America, Asia-Pacific (APAC), Europe, MEA, and Latin America. The United States and Canada are the largest revenue generators in the e-learning market in North America and it is expected that North America will continue to dominate the e-learning market share during the forecast period. In 2017, North America had a market share larger than 43\%, followed by Europe, Middle East, Africa (EMEA) and Asia-Pacific (APAC). America's domination results from improvement of the learning process in the academic sector and the growth of cost-efficient content development. The increase in elearning growth in this region is also affected by the increasingly available Internet infrastructure and the omnipresence of smartphones and tablets in personal use. The comprehensive approach to innovative solutions for learning and training, as well as other advantages, encourage the demand for e-learning modules on the North American market (Arizton Research, 2018).

It can be therefore stated that the corporate e-learning is one of the fastest growing markets and, quite likely, one of the most promising markets in the industry of education. The above statistics clearly show that e-learning is expected to grow and that it has enormous profit potential. Students and corporate users are increasingly opting for e-learning and on-line training to achieve their goals.

The key factor of the e-learning market growth lies in the academic sector. The evolution of education technologies started at schools and universities, where essential hardware and software solutions were used to transform traditional classrooms into digital workshops. Advances in information technology have revolutionised the communication practices and education aspects. Students are submerged in technology that allows new possibilities of learning. Digital tools such as e-learning solutions and e-learning systems allow personalised learning and encourage engagement and development of skills. Digitisation of contents has inevitably resulted in the increase in demand for digital education publications.

\section{Recent Application of E-Learning in Maritime Industry}

Education, training and development of human resources are of vital importance for the sustainability of any industry. This also applies to maritime industry where a significant percentage of sea accidents are caused by human error. Well-trained and competent crews are crucial for the safety of vessels and marine environment. For this reason, maritime industry invests considerable finds and efforts in creating high-quality innovative programs of training. The efficiency of e-learning depends on good and comprehensive learning programs and contents. There are multimedia courses that are designed by a number of companies (Seagull Maritime AS, Videotel, etc.), having various applications in maritime affairs. These courses allow distance learning for the users who are at sea or remote land-based facilities. They are accessible as a physical medium or through the internet. Providers of these courses offer suitable modules, designed for clearly defined learning outcomes, that are supposed to: 1) enable cost-efficiency and time-saving, 2) encourage the learning process via video, text, graphics and animation, 3) engage users in role-play, trouble-shooting and case study activities, 4) provide support through advice, guidelines and assistance in using these courses, etc.

Today, an increasing number of maritime companies use e-learning methods in seafarers' training (MarTID, 2018). Most of the maritime personnel use e-learning as a training method, through video records and bridge or engine room simulators. Traditional classroom teaching, and to a certain extent, simulation training is the most 
popular training tool for operators, with both methods reporting a high usage among respondents. Table 1 presents the statistics of the current training situation in the maritime industry.

Table 1: Statistics of the current situation in training practices in maritime industry (MarTID, 2018)

\begin{tabular}{|c|c|c|c|c|}
\hline \multicolumn{5}{|c|}{ WHICH TRAINING METHOD/S YOUR ORGANIZATION USES: } \\
\hline & High usage & Medium usage & Low usage & Not using \\
\hline Face to face (classroom) & $65 \%$ & $27 \%$ & $8 \%$ & $0 \%$ \\
\hline E-learning video sources & $35 \%$ & $35 \%$ & $19 \%$ & $11 \%$ \\
\hline E-learning Internet based sources & $26 \%$ & $34 \%$ & $31 \%$ & $9 \%$ \\
\hline Simulation & $42 \%$ & $47 \%$ & $6 \%$ & $6 \%$ \\
\hline Table-top exercise & $17 \%$ & $58 \%$ & $22 \%$ & $3 \%$ \\
\hline Job shadowing & $18 \%$ & $41 \%$ & $26 \%$ & $15 \%$ \\
\hline Mentoring & $17 \%$ & $40 \%$ & $29 \%$ & $14 \%$ \\
\hline Coaching & $21 \%$ & $41 \%$ & $21 \%$ & $18 \%$ \\
\hline \multicolumn{5}{|c|}{ ANTICIPATED CHANGE IN TRAINING METHODS USED FOR THE UPCOMING YEAR: } \\
\hline & Increase & Unchanged & Decrease & \\
\hline Face to face (classroom) & $23 \%$ & $54 \%$ & $23 \%$ & \\
\hline E-learning video sources & $43 \%$ & $37 \%$ & $11 \%$ & \\
\hline E-learning Internet based sources & $71 \%$ & $24 \%$ & $6 \%$ & \\
\hline Simulation & $77 \%$ & $14 \%$ & $3 \%$ & \\
\hline Table-top exercise & $38 \%$ & $53 \%$ & $6 \%$ & \\
\hline Job shadowing & $26 \%$ & $56 \%$ & $9 \%$ & \\
\hline Mentoring & $47 \%$ & $37 \%$ & $9 \%$ & \\
\hline Coaching & $50 \%$ & $35 \%$ & $9 \%$ & \\
\hline \multicolumn{5}{|c|}{ USING SIMULATORS TO TRAIN OFFICERS: } \\
\hline & \multicolumn{2}{|l|}{ Bridge officers } & \multicolumn{2}{|l|}{ Engine officers } \\
\hline Delivered primarily in-house & \multicolumn{2}{|l|}{$44.4 \%$} & \multicolumn{2}{|l|}{$30.2 \%$} \\
\hline Delivered primarily in an external facility & \multicolumn{2}{|l|}{$42.2 \%$} & \multicolumn{2}{|l|}{$32.6 \%$} \\
\hline Not used & \multicolumn{2}{|l|}{$13.3 \%$} & \multicolumn{2}{|l|}{$37.2 \%$} \\
\hline \multicolumn{5}{|c|}{ USAGE OF SIMULATION TRAINING IN THE NEXT 5 YEARS: } \\
\hline & Increased use & Leave unchanged & Decreased use & \\
\hline Bridge simulator training & $68.2 \%$ & $18.2 \%$ & - & \\
\hline Engine simulator training & $62.8 \%$ & $18.6 \%$ & - & \\
\hline \multicolumn{5}{|c|}{ ANTICIPATED CHANGE IN INTERNAL VS. EXTERNAL SIMULATOR TRAINING IN THE NEXT 5 YEARS } \\
\hline Use more in-house simulator & \multicolumn{4}{|l|}{$38.1 \%$} \\
\hline Use more external facility simulator & \multicolumn{4}{|l|}{$21.4 \%$} \\
\hline Maintain status quo & \multicolumn{4}{|l|}{$40.5 \%$} \\
\hline
\end{tabular}

In the WMU survey conducted among the former and the present seafarers, roughly $60 \%$ of the respondents indicated their high or medium usage of online e-learning. $70 \%$ used videos and over $80 \%$ used simulators. At least $14 \%$ of respondents indicated that they did not use mentoring or coaching in their organization for training purposes. More than $70 \%$ of the companies anticipate an increase in using simulators and e-learning in the coming years. Almost half of the companies also expect an increase in their usage of mentoring and coaching to help support training (MarTID, 2018).

Simulator training has become the standard when it comes to training bridge officers. Today, over $86 \%$ of the companies use navigating bridge simulators to train deck officers, and around $60 \%$ use simulators to train their engineering officers. Investment into simulation training is increasing. Of the companies that currently make use of simulation training, over $60 \%$ plan to increase the use of simulation for training officers in the next five years. None anticipate a decrease in use of simulation for officer training.

A majority, over $65 \%$, of the companies have their dedicated employees who deliver crew training. Crew training is primarily based on shore activities in classroom. However, both shore-based and onboard training appear to be equally popular. $43 \%$ of the respondents indicated that their training was primarily shore-based, while nearly a third disagreed. Nearly all companies cover transport expenses for their crew training and, similarly, most companies cover transport expenses for their trainers who attend training events. Around half of the companies develop online training and courses in-house, whereas a slightly higher proportion, nearly $60 \%$ of 
the respondents, use 3rd-party online training tools. Around 57\% of the surveyed maritime companies use learning management systems (LMS) to deliver and track online training of their crew. A similar percentage of the companies use blended learning programs (combined on-line and face-to-face) for their crew training. Almost $65 \%$ of companies have a significant formal agreement with a 3rd party training institute, i.e., with a shore-based maritime education and training institution such as a maritime academy, college or university (MarTID, 2018).

In most cases, the education of seafarers takes place in two separate systems. One of them includes primary and secondary schooling, the other consists of specific training programs that are in line with the requirements of the International Convention on Standards of Training, Certification and Watch keeping for Seafarers (STCW), i.e. a convention which is not part of the formal educations system. In order to enable greater flexibility in maritime workforce education, the International Maritime Organization (IMO) introduced education standards for seafarers through STCW 78, introducing minimum competence requirements the seafarers have to meet but also, at the global level, resolving the issue of the recognition of national certificates of competence and the comparison of various national education and training programs. In addition, IMO has released a number of recommended programs with standardised guidelines with the purpose of facilitating the implementation of STCW regulations across the education and training institutions. Most of these contents refer to specific training programs (courses) that are necessary for acquiring adequate knowledge and skills. Specifying the work hours spent in lectures, auditory and laboratory exercises, and other forms of learning.

Companies typically use a higher percentage of in-house training for all areas of training except STCW competencies. A little over half of the companies will outsource their STCW-related training. According to the surveyed respondents, $10 \%$ think that the STCW is not aligned with industry needs and that it needs to be updated to become more relevant. Conversely, a similar proportion of respondents believe that the current STCW Convention and Code is adequate for international training, provided that it is implemented effectively. The STCW experienced serious changes in 1995, with the new amendments being introduced in Manila in 2010. One of them was the introduction of e-learning and distance-learning (Section B-I/6). These education and training approaches have been recognised as means of education of seafarers but have never been clearly defined.

\section{Future Application of E-Learning in Maritime Industry}

In the computer-aided game industry it is standard practice that the clients use virtual reality (VR) devices for completing computer games or simulations on their personal computers (e.g. Oculus Rift), home playing consoles (e.g. Playstation VR) or smartphones (e.g. Samsung Gear VR), because these technologies have become available to mass users. Likewise, the technology providing augmented reality (AR) is expected to become widely available in the years to come. These are the reasons for integrating the above technologies into the e-learning process, especially in maritime industry that requires specific skills, easier familiarisation and operation with specific types of vessels. A learner would be able to acquire essential insights and skills related to his/her profession in a faster and easier way. Students and seafarers requiring specific training when entering or advancing through their maritime-related careers could have huge benefits from the VR and AR technologies. This way of learning could create entirely new possibilities, allowing the user to learn through experience, on the basis of his or her hits and misses, but without serious consequences that are inevitable in real life. Many companies have recognised the advantages of the new technologies. Video and Internet training providers for seafarers, such as KVH Videotel, have established cooperation with other companies engaged to design software and modules that are able to create a range of scenarios and tasks for trial-and-error learning and gaining virtual experience. Moreover, it is possible to use these technologies in self-learning and self-acquisition of the skills that are peculiar to seamanship and maritime affairs, including survey of the life-saving equipment, responding to emergency on board ship, cargo handling, using the sextant and nautical triangles, berthing, anchoring, etc. At this moment, however, these are just assumptions, and further detailed research should be carried out to find out to what extent the VR and AR are able to assist students, through individual or team work, in acquiring some (or all) of the skills in the specific segments of the maritime industry.

When considering the future development of VR learning in any industry, students will no longer need strong computers with advanced graphic cards and architecture, because vendors will stream e-learning in virtual environment through the Internet onto the user's touch screen of standard screen fitted with mouse and keyboard. The user's hardware parameters will be irrelevant as the main graphic tasks will be performed by the server and the only relevant parameter will be the speed of the Internet connection, i.e., the speed of streaming. 
This development of technology changes the concept of financial investment by the colleges, universities and other learning facilities which will be paying for the provider's services instead of investing in expensive hardware. Figure 2 shows this new concept of virtual reality e-learning in maritime industry.

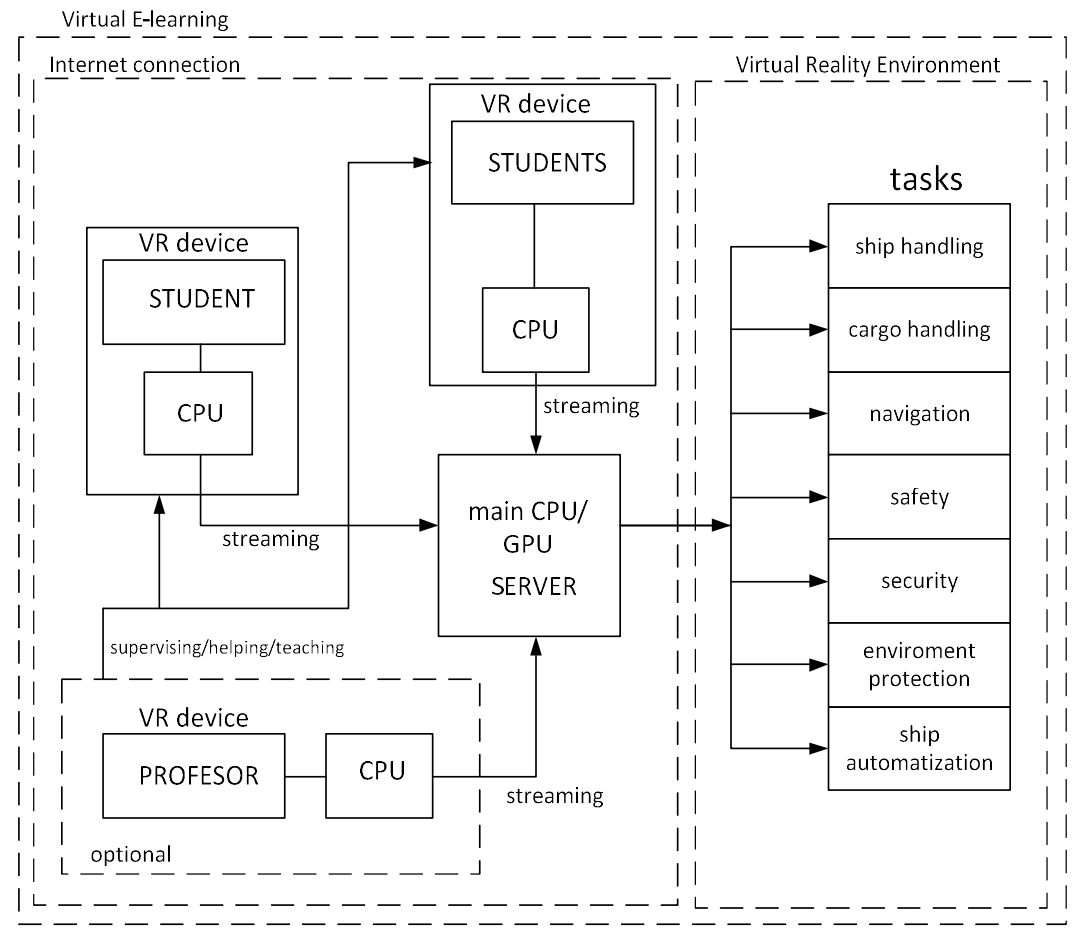

Fig. 2: Concept of virtual e-learning in maritime industry

Taking the above discussion into consideration, future online education is likely to be integrated everywhere and available anywhere, including remote locations such as commercial ships at sea, by applying the advanced technologies: video content, gaming programs, VR and AR elements. The main goal of the e-learning modules will be to offer continuous and effective learning at an optimal cost and to provide customized course content that meets the specific requirements of seafarers and shore-based personnel.

Finance remains a great challenge for all institutions engaged in the education and training of seafarers. Funds for investing in simulators and new technologies are often limited. Another issue is the availability of special education and training courses and the lack of competent and committed staff for training and assessment. Future forecasts indicate that these problems will remain: there will be a shortage of qualified training personnel and safe jobs for instructors. Other problems will include financial restrictions, fast digitisation and rapid development of technologies in maritime industry and the attractiveness of jobs that will be created. One of the most prominent challenges that the industry will face in the following years will be the reduced manning on board ships and reduced demand for workforce. The rapid growth of technologies will further facilitate the process (Lusic, et al, 2019).

\section{Further Research into E-learning in Maritime Industry}

Education and training of seafarers outside classrooms or in absence of instructors is a very complex process. Distance-learning on board a ship requires considerable concentration, avoiding the overlapping with regular duties and buying time off for the purpose of learning. This requires reliable internet connections, careful planning and consultation with instructors who may be in other time zones, etc. A number of research studies confirm that an adult needs at least 7 to 9 hours of sleep to function normally and carry out daily tasks efficiently. This is particularly important for seafarers whose work is often hard and stressful. The problem of the conventional learning systems lies in the time spent in organised learning activities, i.e. in the time spent in lectures, exercise, workshops and other forms of training. Another issue arising from the conventional methods 
is the teacher's competence, i.e. the way he or she can transfer knowledge efficiently and how familiar he or she is with the practice and implementation of new technologies in maritime affairs. Furthermore, the common feature of all standard forms of education and training is that the process takes place in class and through conventional methods. This results in a number of disadvantages regarding the optimisation of learning schedule as the seafarers are required to be physically present in learning facilities instead spending time with their families. Besides, the very nature of their work makes their attendance difficult. Finally, conventional forms of education and training require a specific organisation of activities with regard to spatial, material and human resources of the learning facilities.

Market critics agree that e-learning has a lot of room for growth in various sectors of economy, including maritime industry. E-learning is entering the area of seaborne transport technology, although not so fast as in other sectors of economy (Allan, 2013). The reasons may include the specific requirements of the maritime industry and the practical skills that can efficiently mastered only through face-to-face training. The strengths, weaknesses, opportunities and threats of e-learning in maritime affairs are presented through the SWOT analysis in Table 3. It shows that the sea-borne shipping is one of the most stringently controlled industries, with a number of complex regulations, guidelines and standards at national and international levels, including the IMO regulations on working standards in seafaring and regulations on marine environment protection.

Extensive research into the potential benefits of e-learning in the area of seafaring has been conducted and it has been proved that a portion of knowledge and skills can indeed be transferred in this way, e.g. collision avoidance (Mohović, 2016). However, the question is whether e-learning is entirely applicable to maritime industry. The STCW 2010 Manilla amendments contain Guidance for use of distance learning and e-learning (Section B-I/6.6-6.10), but the suggested guidance is limited. The appropriate application of the training model is described through defining the executive syllabi and workload, but there is no definition on the amount of content and work hours that may be performed through distance learning and the work that should be carried out through traditional in-class activities. Some courses containing elements of STCW programs require specific skills (e.g. ship and boat handling, working with navigation triangles, sextant, life-saving equipment, cargo equipment, communication devices, etc.), and it is absolutely necessary to determine when and to what extent the e-learning approach is efficient in education and training of seafarers, i.e. to what extent it should be combined with conventional learning methods that are otherwise vital in courses whose content cannot be delivered through e-learning. Recently the IMO Sub-Committee also discussed the possible conversion of IMO model courses to e-learning versions and agreed to advise the Maritime Safety Committee (MSC), as the parent body, that this would need further careful consideration. Converting to e-learning would change the current approach and goals of IMO model courses. However, the Sub-Committee on Implementation of IMO Instruments (III) might be asked to consider how e-learning material could assist with the implementation of instruments other than the STCW Convention (www.imo.org).

The system of the education and training of seafarers or the maritime studies comprise general and professional subjects as well as a great deal of specific content focused on acquiring specific skills and knowledge. Elearning alone cannot respond to all these needs. True, e-learning can contribute to the quality and efficiency of seafarers' education and training but the areas and limits have not yet been defined in practice. In addition, a number of questions emerge when discussing the application of e-learning: 1) To what extent, or in which percentage, can e-learning be helpful in self-paced learning activities? 2) Where is the adequate boundary between the web-based and traditional in-class contents and materials? 3) Can a seafarer accept the available elearning material during on-board service? 4) How efficient can a seafarer be in allocating time for self-paced learning while on board, i.e. does he/she have enough time for mastering demanding tasks? 5) Are there ways to contact the instructors for specific training modules via information technologies such as e-mail, text messaging, VoIP (Voice over Internet Protocol) programs or video communications, and the like, in case a seafarer needs additional information regarding the course? Needless to say, seafarers are required to master a variety of skills and practices, and e-learning may not be the best option for meeting these needs. It should be also pointed out that e-learning heavily relies on online technologies, that access to the internet is sometimes dependent on the corporate policies or on physical constraints, e.g. when some ships are in port or close to ports, while other ships may have internet connection via satellite. These issues have formed the groundwork for the logic matrix analysis of e-learning in maritime affairs, as presented in Table 2. The main factors - such as the logic of action, indicators of e-learning performance, sources and resources, and assumptions - are used to define goals, expected outcomes and activities of e-learning in maritime affairs. 
Table 2: SWOT analysis of e-learning in maritime affairs

\begin{tabular}{|c|c|c|c|}
\hline STRENGTHS & WEAKNESSES & OPPORTUNITIES & THREATS \\
\hline Distance education & $\begin{array}{l}\text { Requires certain knowledge } \\
\text { and skills for using e-learning } \\
\text { tools. }\end{array}$ & $\begin{array}{l}\text { M-learning as a part of e-learning } \\
\text { allows considerable transfer of } \\
\text { content by replacing books and } \\
\text { notes with small devices that are } \\
\text { adjusted to the learning content. }\end{array}$ & $\begin{array}{l}\text { Individual evaluation of the need } \\
\text { for learning, which may lead to } \\
\text { questionable results and poor } \\
\text { progress in the process of learning. }\end{array}$ \\
\hline $\begin{array}{l}\text { Simultaneous } \\
\text { participation of a number } \\
\text { of users. }\end{array}$ & $\begin{array}{l}\text { E-learning is heavily dependent } \\
\text { on online technologies. }\end{array}$ & $\begin{array}{c}\text { Advancements in mobile technology } \\
\text { change the basic purpose of mobile } \\
\text { devices. }\end{array}$ & $\begin{array}{l}\text { Serious games can serve as an } \\
\text { alternative way of learning but the } \\
\text { efficiency of this approach to e- } \\
\text { learning should be assessed } \\
\text { scientifically. }\end{array}$ \\
\hline $\begin{array}{l}\text { Form of learning that can } \\
\text { take place while a student } \\
\text { is not at a fixed pre- } \\
\text { determined location. }\end{array}$ & $\begin{array}{l}\text { Financial constraints of } \\
\text { institutions engaged in } \\
\text { education and training of } \\
\text { maritime industry personnel } \\
\text { when investing in e-learning } \\
\text { equipment. }\end{array}$ & $\begin{array}{l}\text { Possibility of learning at various } \\
\text { locations. }\end{array}$ & $\begin{array}{l}\text { Thorough research is required to } \\
\text { define to what extent can VR and } \\
\text { AR assist a student in mastering } \\
\text { specific maritime skills } \\
\text { individually or in group. }\end{array}$ \\
\hline $\begin{array}{l}\text { E-learning is available } \\
24 / 7 \text {, which enables the } \\
\text { user to spend time } \\
\text { efficiently. }\end{array}$ & $\begin{array}{l}\text { Even the cutting-edge e- } \\
\text { learning equipment is not } \\
\text { entirely reliable. }\end{array}$ & $\begin{array}{l}\text { Access to databases and interaction } \\
\text { with instructors and students. }\end{array}$ & $\begin{array}{l}\text { One of the challenges that the } \\
\text { maritime industry faces is the } \\
\text { shortage of competent and } \\
\text { committed staff for training and } \\
\text { evaluation. }\end{array}$ \\
\hline $\begin{array}{l}\text { Available virtually } \\
\text { anywhere. Instant sharing } \\
\text { across the student } \\
\text { population. }\end{array}$ & $\begin{array}{l}\text { The need for self-motivation. } \\
\text { Individual evaluation of the } \\
\text { need for learning, which may } \\
\text { lead to questionable results and } \\
\text { poor progress in the process of } \\
\text { learning. }\end{array}$ & $\begin{array}{l}\text { Ability to analyse information } \\
\text { within student environment. }\end{array}$ & $\begin{array}{l}\text { Many maritime education and } \\
\text { training companies have financial } \\
\text { constraints regarding investments } \\
\text { in simulator and new training } \\
\text { technologies. }\end{array}$ \\
\hline $\begin{array}{l}\text { The systems allows } \\
\text { simple integration and } \\
\text { access to other sources } \\
\text { that are relevant to the } \\
\text { learning content. }\end{array}$ & $\begin{array}{l}\text { Huge investments in creating } \\
\text { innovative training programs. }\end{array}$ & $\begin{array}{l}\text { The key factor of the e-learning } \\
\text { market growth is the academic } \\
\text { sector. }\end{array}$ & $\begin{array}{l}\text { Companies engaged in training } \\
\text { may have difficulties in purchasing } \\
\text { or finding available training } \\
\text { courses. }\end{array}$ \\
\hline $\begin{array}{l}\text { By making individual } \\
\text { decisions on the form and } \\
\text { time of learning, e- } \\
\text { students take greater } \\
\text { responsibility. }\end{array}$ & $\begin{array}{l}\text { Efficient e-learning requires } \\
\text { personality skills: self- } \\
\text { orientation, motivation, } \\
\text { discipline, independence and } \\
\text { persistence in solving tasks. }\end{array}$ & $\begin{array}{l}\text { While entering and advancing } \\
\text { through the maritime industry, } \\
\text { students and seafarers can have } \\
\text { great benefits from the VR and AR } \\
\text { technologies. }\end{array}$ & $\begin{array}{l}\text { Future forecasts predict serious } \\
\text { challenges, including the shortage } \\
\text { of qualified training personnel and } \\
\text { safe jobs for instructors, financial } \\
\text { restrictions, fast digitisation and } \\
\text { rapid development of technologies } \\
\text { in maritime industry. }\end{array}$ \\
\hline $\begin{array}{l}\text { The latest information is } \\
\text { available at one place. }\end{array}$ & $\begin{array}{l}\text { May lead to questionable } \\
\text { results and poor progress in the } \\
\text { process of learning. }\end{array}$ & $\begin{array}{l}\text { Allows the user a relatively easy } \\
\text { access to needed information. }\end{array}$ & $\begin{array}{l}\text { Attractiveness of seafaring jobs for } \\
\text { future generations. }\end{array}$ \\
\hline
\end{tabular}


Table 3: Logic matrix analysis of e-learning in maritime affairs

\begin{tabular}{|c|c|c|c|c|}
\hline & Logic of action & $\begin{array}{l}\text { Impartially verifiable } \\
\text { indicators of } \\
\text { performance }\end{array}$ & $\begin{array}{c}\text { Sources and evaluation } \\
\text { tools }\end{array}$ & Assumptions \\
\hline $\begin{array}{l}\text { General } \\
\text { goals }\end{array}$ & $\begin{array}{l}\text { E-learning allows the } \\
\text { learner a relatively } \\
\text { easy access to needed } \\
\text { information. }\end{array}$ & $\begin{array}{l}\text { Growing interest in } \\
\text { continuous learning } \\
\text { and in using learning } \\
\text { technologies anytime } \\
\text { and anywhere drives } \\
\text { the growth of this } \\
\text { segment in the global } \\
\text { e-learning market. }\end{array}$ & $\begin{array}{l}\text { International Maritime } \\
\text { Organization, regulations of } \\
\text { the STCW Conventions, } \\
\text { national regulations. }\end{array}$ & $\begin{array}{l}\text { In the future, e-learning } \\
\text { should be integrated } \\
\text { everywhere, through the } \\
\text { application of advanced } \\
\text { technologies: video content, } \\
\text { elements of virtual or } \\
\text { augmented reality. }\end{array}$ \\
\hline $\begin{array}{l}\text { Specific } \\
\text { goals }\end{array}$ & $\begin{array}{l}\text { Education, training } \\
\text { and development of } \\
\text { human resources are } \\
\text { essential for the } \\
\text { survival of each } \\
\text { economy sector, } \\
\text { including the } \\
\text { maritime industry. }\end{array}$ & $\begin{array}{l}\text { Increased use of } \\
\text { simulation tools for } \\
\text { deck and engine } \\
\text { officer training is } \\
\text { planned over the next } \\
5 \text { years. }\end{array}$ & $\begin{array}{l}\text { International Maritime } \\
\text { Organization, regulations of } \\
\text { the STCW Conventions, } \\
\text { national regulations. }\end{array}$ & $\begin{array}{l}\text { A shift is expected toward } \\
\text { cloud-based learning that is } \\
\text { cost-effective, efficient and } \\
\text { time-saving, which will } \\
\text { encourage the growth of the } \\
\text { corporate sector on the e- } \\
\text { learning market. }\end{array}$ \\
\hline $\begin{array}{l}\text { Expected } \\
\text { outcomes }\end{array}$ & $\begin{array}{c}\text { Expected outcomes: } \\
\text { video files, Internet } \\
\text { and simulations are } \\
\text { used as part of } \\
\text { seafarers' training. } \\
\text { Over } 70 \% \text { of } \\
\text { maritime companies } \\
\text { anticipate an increase } \\
\text { in the usage of } \\
\text { simulators and e- } \\
\text { learning in the } \\
\text { following years. }\end{array}$ & $\begin{array}{l}\text { Growing demand of } \\
\text { the corporative sector } \\
\text { for independent } \\
\text { learning will create } \\
\text { new opportunities for } \\
\text { vendors in this market } \\
\text { during the forecast } \\
\text { period. }\end{array}$ & $\begin{array}{l}\text { International Maritime } \\
\text { Organization, regulations of } \\
\text { the STCW Conventions, } \\
\text { national regulations. }\end{array}$ & $\begin{array}{l}\text { The academic sector } \\
\text { (colleges, universities, etc.) } \\
\text { is propelling the growth of } \\
\text { training segment in the } \\
\text { global e-learning market. }\end{array}$ \\
\hline Activities & $\begin{array}{l}\text { Well-trained and } \\
\text { competent crews are } \\
\text { essential for the } \\
\text { safety of the ship and } \\
\text { marine environment. } \\
\text { For this reason, } \\
\text { considerable funds } \\
\text { are invested in } \\
\text { creating innovative } \\
\text { training programs. }\end{array}$ & $\begin{array}{l}\text { Political and financial } \\
\text { resources. } \\
\text { Considerable funds } \\
\text { are invested in } \\
\text { creating innovative } \\
\text { training programs in } \\
\text { the maritime industry. }\end{array}$ & $\begin{array}{l}\text { International Maritime } \\
\text { Organization, regulations of } \\
\text { the STCW Conventions, } \\
\text { national regulations. }\end{array}$ & $\begin{array}{l}\text { In order to become } \\
\text { competitive, e-learning } \\
\text { must meet the expectations } \\
\text { of students and yield good } \\
\text { learning outcomes at } \\
\text { acceptable costs. }\end{array}$ \\
\hline
\end{tabular}

\section{Conclusion}

Modern maritime industry is governed by a number of national and international regulations, conventions and guidelines aimed at safety at sea and efficiency in seaborne shipping. The development of new technologies and new requirements of the maritime industry have resulted in changes in the seafarers' education and training system over the past decade. After the World War II, the system of seafaring staff education developed proportionally to the requirements of the technological progress. However, even today, the vessel remains a relatively unsafe place to work, and the life of seafarers remains hard and stressful. Owing to the new technologies, personal computers have become omnipresent and various sources of information accessible from anywhere, anytime. Besides having a considerable impact on our daily routine, the new technologies have introduced e-learning as a form of education that allows a student to independently determine the way, content and time of learning. The performed SWOT analysis and logic matrix analysis of e-learning in maritime affairs clearly reveal certain drawbacks of this form of learning, as it makes the student responsible for the independent 
organisation of learning activities, he or she must be motivated and has to individually assess the need for learning, which may lead to questionable results and poor progress in the process of learning. In order to perform self-paced e-learning, the student must feature self-orientation, motivation, good command of computer and web-based services, affinity for reading and writing, discipline, independence and persistence in task solving. Moreover, e-learning and m-learning require specific skills in their own right. This form of learning is gradually entering the area of seaborne transportation technologies, although it has not been embraced to the extent it has been accepted in other industries. The education and training of seafaring officers comprise a number of specific elements, including knowledge, skills, attitude, personality, experience, and the like, that cannot be adequately enhanced independently, only through e-learning. It can be therefore stated that e-learning cannot fully replace the traditional forms of seafarers' education and training. The formal learning workload, content, teaching staff and material-technical conditions have been described by the International Maritime Organization (IMO), and the shares of this education and training to be delivered via e-learning and face-to-face traditional learning have not been defined yet. However, the new technologies are creating the possibility for the introduction of e-learning and m-learning into on-board working environment. The amended STCW Convention has recognised the advantages of e-learning but the future research into this complex matter should fully defined these advantages. The most serious problems related to the introduction of e-learning in maritime industry include the shortage of qualified training personnel and safe jobs for instructors, financial restrictions, fast digitisation and rapid development of technologies in maritime industry, but also the attractiveness of seafaring jobs for future generations. It is expected that, in the near future, the development of technologies will enable the application of VR and AR technologies so that learners might master a share of specific knowledge and skills independently. As the international seaborne transport is expected to grow in the following years, the issue of seafarers' education and training, and e-learning as its component, remains increasingly challenging.

\section{References}

Delen, E., Liew, J. and Willson, V. (2014): Effects of interactivity and instructional scaffolding on learning: Selfregulation in online video-based environments, Computers \& Education Journal, Vol. 78, pp. 312-320. https://doi.org/10.1016/j.compedu.2014.06.018

Bauk, S., Radlingera, R (2013): Concerning web-based e-learning at a maritime higher education institution: case study, Transactions on Maritime Science (ToMS), Vol. 2, pp. 115-122. https://doi.org/10.7225/toms.v02.n02.004

O'Dwyer, E.C. (2001): Approaches to distance learning - an evaluation of current methodologies, technologies and operational costs as an alternative means of course delivery for developing country academies, World Maritime University, Sweden, dissertation.

Koroleva, E.A., Makashina, I.I., Filatova E.V., Mamunts D. G., Zhukov V.A. (2018): Advantages of networking and distance learning use in maritime education and training, IEEE Conference of Russian Young Researchers in Electrical and Electronic Engineering (EIConRus), pp. 61-65. https://doi.org/10.1109/EIConRus.2018.8317030

Huang, Y.(2014): Empirical analysis on factors impacting mobile learning acceptance in higher engineering education, The University of Tennessee, Knoxville, USA, dissertation.

Marc B., Rasmus, P.(2012): Acceptance, chances, and problems of mobile learning in vocational education in enterprises; CEUR-WS.org Workshop Proceedings, Vol. 955, pp.190-196.

Accuray Research LLP (2019): Global e-learning market analysis \& trends - industry forecast to 2027, research study.

Arizton Research (2018): E-learning market - global outlook and forecast 2018-2023, research study.

Maritime Training Insights Database (2018): Training Practices Report, World Maritime University, research study.

STCW (2017): STCW including 2010 Manila amendments, International Maritime Organization.

Lušić, Z., Bakota, M., Čorić, M., Skoko, I (2019): Seafarer market - challenges for the future, Transactions on Maritime Science Vol. 8, No. 1, pp 62-74. https://doi.org/10.7225/toms.v08.n01.007

Allan, C., Symes, M., Downing, J.(2013): Identifying e-learning principles for maritime education through the e-initiatives project: a design-based approach, 30th Ascilite Conference, Macquarie University, Sydney, pp.1-4.

Mohovic, D., Mohovic, R. and Mate Baric (2016): Deficiencies in learning colregs and new teaching methodology for nautical engineering students and seafarers in lifelong learning programs, The Journal of Navigation, The Royal Institute of Navigation, Vol. 69, pp. 765-776.

https://doi.org/10.1017/S037346331500096X

Watchkeeping, HTW 6th session, 19 April - 3 May 2019 (www.imo.org). 